\title{
Research on College Oral English Teaching Based on Whole Language Approach
}

\author{
Zhang Wei \\ Jilin Business and Technology College \\ 182076127@qq.com
}

\begin{abstract}
Whole language approach, as an education concept, has a great influence on language teaching. Whole language approach takes language itself as an entirety, paying attention to cultivating the students' comprehensive language ability and expanding the category of language teaching to other aspects related to students' life. This paper introduces the concept of whole language approach, and on the basis of it, discusses how to put the language theory and teaching methods into the college oral English teaching, thus forming an effective teaching mode. This mode reflects the communicativeness of classroom teaching, the diversification of teaching form and the centralized characteristics of students. The teaching mode has an effect on the direction and promotion of the theory and practice of oral English teaching reform.
\end{abstract}

Keywords-whole language approach; college oral English teaching; oral English teaching reform

\section{INTRODUCTION}

In the 21st century, economic globalization has greatly promoted the process of the internationalization of China, people concern more about English, the medium of international culture and academic exchange. How to learn English well and improve English application ability has become a commonly concerned issue of the society. In the new situation, College English Curriculum Requirements puts forward a new college English teaching goal to cultivate the students' comprehensive application ability of English, especially listening and speaking skills and make them competent to written and spoken communication in the social activities of future work. The college English examination committee of education ministry established the speaking test in CET 4 and CET 6 since May 19th in 1999 and put forward the great reform of the test questions in CET 4 and CET 6, increasing the proportion of listening and speaking. Thus, college oral English teaching has been attached ever great importance to and its importance has been widely acknowledged. In this paper, the whole language approach and teaching method prevailing in the US is introduced, on the basis of which the paper further discusses how to combine the teaching method with the college oral English teaching, so as to form an effective teaching mode and find efficient ways of oral English teaching.

\section{WhOlE LANGUAgE APPROACH AND WHOLE LANGUAGE TEACHING METHOD}

In the 1990s, the whole language approach and whole language teaching method were widely recognized in the US and Canada and gradually being applied to foreign language teaching. However, the whole language approach receives little recognition in China and is seldom used in English teaching[1].

\section{A. Overview of whole language approach}

The term Whole Language was created in the 1980s by a group of U.S. educators concerned with the teaching of language arts (Richards \& Rodgers, 2001). The Whole Language Approach emphasizes learning to read and write naturally with a focus on real communication and reading and writing for pleasure. In the 1990s, it became popular in the United States as a motivating and innovating way of teaching language arts skills to primary school children. It shares a philosophical and instructional perspective with Communicative Language Teaching because it emphasizes the importance of meaning and meaning making in teaching and learning. It also relates to natural approaches to language learning since it is designed to help children and adults learn a second language in the same way that children learn their first language. Whole language describes a literacy philosophy which emphasizes that children should focus on meaning and strategy instruction. It is often contrasted with phonics-based methods of teaching reading and writing which emphasize instruction for decoding and spelling. However, from whole language practitioners' perspective, this view is erroneous and sets up a false dichotomy. Whole language practitioners teach to develop knowledge of language including the graphophonic, syntactic, semantic and pragmatic aspects of language. Within a whole language perspective, language is treated as a complete meaning-making system, the parts of which function in relational ways. It has drawn criticism by those who advocate "back to basics" pedagogy or reading instruction because whole language is based on a limited body of scientific research.

The idea of "whole" language has its basis in a range of theories of learning related to the epistemologies called "holism". Holism is based upon the belief that it is not possible to understand learning of any kind by analyzing small chunks of the learning system. Holism was very much a response to behaviorism, which emphasized that the world could be understood by experimenting with stimuli and responses. 
Holists considered this a reductionist perspective that did not recognize that "the whole is greater than the sum of its parts." Analyzing individual behaviors, holists argued, could never tell us how the entire human mind worked. This is-in simplified terms - the theoretical basis for the term "whole language". The whole language approach to phonics grew out of Noam Chomsky's ideas about language acquisition. In 1967, Ken Goodman had an idea about reading, which he considered similar to Chomsky's, and he wrote a widely cited article calling reading a "psycholinguistic guessing game”. He chided educators for attempting to apply what he saw as unnecessary orthographic order to a process that relied on holistic examination of words[2].

In the simplest terms, the "whole language approach" is a method of teaching children to read by recognizing words as whole pieces of language. Proponents of the whole language philosophy believe that language should not be broken down into letters and combinations of letters and "decoded.” Instead, they believe that language is a complete system of making meaning, with words functioning in relation to each other in context.

\section{B. Features of whole language approach}

Based on the overall language view and overview of the whole language teaching, the overall meaning of the "whole language teaching" objectively reflects the three aspects education involves: the teaching object-the target language; the teaching subject-students and teaching environmentteaching conditions and teaching purposes. This shows that the whole language teaching in the field of foreign language teaching sets up an overall, multi-integrated, comprehensively balanced and highly harmonious new pattern. In particular, the teaching concept has the following characteristics:

\section{1) Highlight the integrity of language, namely the whole language.}

In the process of teaching, based on the new concept of language teaching, language is not separated into pronunciation, vocabulary, grammar, etc. Instead, language teaching must proceed from the whole to cultivate students' basic skills of listening, speaking, reading and writing, at the same time, the synchronous development of students' language skills must be paid attention to[3].

\section{2) Pay attention to student's entirety, that is, the whole learners.}

All personal factors of students must be given consideration to in the process of teaching, including their interest, motivation, demand, purpose, will and learning strategies, etc. Effective language teaching should not violate the natural process, but should adapt to the natural process; It should not hinder the students to learn, but should help students learn and improve learning; It cannot let students adapt to teachers and teaching materials, but should make teachers and teaching materials adaptive to students, insisting that students play a principal role in the process of teaching organization.
3) Pay attention to the teacher's integrity, namely the whole teachers.

The teacher's role is no longer the authority of knowledge but to learn together, work together and create, discovery, knowledge and skills together with students, that is to say, teachers play a consulting, counselling, inspiring, motivating and organizing role. In the process of the implementation of teaching, teachers should have high theoretical level and practice level and professional dedication to implement the teaching goal, teaching content, teaching method, and have a high degree of flexibility, so as to meet the needs of the learners with the most effective way4[.

\section{4) Pay attention to the integrity of the teaching material, that} is, the whole texts.

The integrity of the teaching material includes the attractiveness, practicability and universality of teaching materials. Language level of the material should be consistent with the basic knowledge level of the learners and teaching materials are written for the purpose of teaching based on real communication goals rather than the textbooks.

\section{5) Pay attention to the integrity of the teaching method, namely the whole skill.}

The integrity of the teaching method does not mean that teachers adopt all the methods but adopt what kind of method, in accordance with the main purpose, teaching place and time, specific objects and specific environment. Assessment methods are also different from the traditional test method. Teachers should create folders for each student and adhere to the periodic evaluation combined with summative assessment.

\section{6) Pay attention to the integrity of the learning environment, that is, the whole environment.}

In the teaching process, it is necessary for teachers to create a kind of respectful, attentive and refreshing atmosphere for students to show their self-value and relax their minds. Opportunities should also be created for students in terms of verbal expression, so as to cultivate their communicative competence. Cooperation teaching is another teaching method in which students forms a partnership of cooperation, make the whole class involve into group activities. Teachers can recommended all kinds of books and periodicals as reading materials for students and encourage students to participate in the English corner, English salon, English club and other activities, so that the students can live in the use of target language environment.

\section{College ORAl ENGLish TEACHING IN THE GUIDANCE OF WHOLE LANGUAGE APPROACH}

From the above theoretical elaboration, we can come to the conclusion the major teaching principles of whole language teaching, see Table 1. 
TABLE I. MAJOR PRinciples of Whole LANGUAge Teaching

\begin{tabular}{|l|l|}
\hline $\begin{array}{l}\text { (1)Take the three } \\
\text { elements of language } \\
\text { (pronunciation, } \\
\text { vocabulary and } \\
\text { grammar) as a whole }\end{array}$ & $\begin{array}{l}\text { not advocating cutting teaching activities into } \\
\text { pieces, conducting analytical construe } \\
\text { positively or practicing mechanically and } \\
\text { repetitively }\end{array}$ \\
\hline $\begin{array}{l}\text { (2)Take listening, } \\
\text { speaking, reading and } \\
\text { writing as a whole }\end{array}$ & $\begin{array}{l}\text { not arguing to separate listening, speaking, } \\
\text { reading and writing from one another }\end{array}$ \\
\hline $\begin{array}{l}\text { (3)Take learning and } \\
\text { application as a whole }\end{array}$ & $\begin{array}{l}\text { The ultimate goal of learning foreign } \\
\text { language is to use the learned language to } \\
\text { express and perform social functions }\end{array}$ \\
\hline $\begin{array}{l}\text { (4) Take students and } \\
\text { teachers as a whole }\end{array}$ & $\begin{array}{l}\text { thinking English teaching process to be a } \\
\text { process of interaction and influence between } \\
\text { teachers and students }\end{array}$ \\
\hline $\begin{array}{l}\text { (5) Take the students' } \\
\text { needs and the realistic } \\
\text { teaching environment as } \\
\text { a whole }\end{array}$ & emphasizing learner centered orientation \\
\hline
\end{tabular}

Based on the above teaching principles, in college oral English teaching, we must start from the following aspects:

\section{A. Adjust the teaching goals.}

The current college English teaching goals and requirements are vague and general, especially on the requirements of speaking ability, which is a "weakness". To make the "product" output from college qualified, college English teaching must highlight the oral English teaching and enhance students' communicative competence. On the specific operation, teachers can make the teaching goals systematic and periodical. In the first semester, it focuses on basic language quality, such as strengthening the pronunciation and intonation and cultivating good habits of autonomous training and ability; In the second semester, teaching goals attach more importance to listening skills, generalization ability and communication strategy training; In the third and fourth semester, it focuses on communication, debate and speech ability training; Intercultural communication training can also be organized in junior and senior grades. This method can achieve the overall goal without much difficulty because it is operable and also can realize continuity of college English teaching[5].

\section{B. Adhere to the principle of taking the students as the main body.}

In the implementation and management of oral English teaching, while the overall planning and the whole advancement are very important, seeing the students' individual differences in interest, habits, intelligence and other aspects, flexible and pragmatic highlighting on the personalized teaching and management can more reflect the modern foreign language education concept and humanistic spirit. For instance, students can choose their teachers optionally, decide the classroom learning tasks and can even alternate the learning contents, etc.[6]. In this way, students are really taken as the center of English teaching, which is more likely to discover the students' individual potential, improve their oral English training enthusiasm and sense of responsibility.
C. Optimization of the teaching material can provide the best language sample so as to inspire students' emotional motivation to receive oral English training to the maximum.

The edition of teaching material for oral English not only follows the rules of language learning and the general teaching principle, but also conforms to the people-oriented principle, which is close to the era. At the same time, to accomplish the purpose of communication and the pursuit of truth, choosing some teaching material which is closely related to the topic of contemporary life and especially in accordance with college students' life can not only achieve the goal of language training but also increase knowledge, so as to make English become a really efficient communication tool [7].

\section{The innovation of classroom teaching mode.}

With the wide application of modern multimedia technology, college oral English class should form an integrated mode with teachers, students and network courseware series involved, namely, the students under the guidance of teachers follow the courseware programs and specific tasks and carry out a large number of real efficient imitation practice, man-machine dialogue, information feedback and activity evaluation and so on, so that it can truly take the students as the center of teaching, provide equal opportunities for students to participate in and effectively improve the classroom efficiency and students' ability of selfevaluation.

\section{E. Scientific evaluation of oral output.}

Students will inevitably make language mistakes in the process of language output, which is a normal phenomenon, so, the teacher should have the right attitude towards this phenomenon. Spoken language output is a communicative process, college oral English teaching is supposed to focus on the communicative purposes and results, rather than entangle the communication process. Those mistakes which affect communication or interfere with the result of the communication should be corrected immediately, while some improper speech and grammar mistakes needn't be given too much consideration. Teacher's evaluation of students' oral output is to give an accurate positioning for the students' ability of oral English from the language's breadth, accuracy, coherence and appropriateness, namely, from the point of view of relevant expression and the output of discourse coherence to make a positive evaluation of students, so as to arouse the students' interest in English learning[8].

\section{CONCLUSION}

College English education, especially oral English teaching, is supposed to change the teaching concept and be based on the situation of foreign language education in our country, which determines college oral English teaching to draw lessons from foreign research results, pay attention to cultivate students' innovation spirit and practice ability and thus improve the quality of teaching, achieve all-round development and cultivate qualified foreign language talents. It is an urgent task in front of the foreign language workers. The research on 
whole language approach and its application in college oral English teaching conducted in this paper is in the hope of playing a referential role in the contemporary and future college oral English teaching in China.

\section{REFERENCES}

[1] Bo Rong and F. Dai, An application of whole language approach to the lingual teaching experience, Vocational Technological Education 11, pp. 49-50, 2009.

[2] R. Liu and H. Lv, A study of application of whole language approach on the English listening and speaking education, Journal of Chifeng College 9, pp. 68-69, 2011
[3] Borowsky R, Cummine J, Owen WJ, Friesen CK, Shih F, Sarty GE (2006). "FMRI of ventral and dorsal processing streams in basic reading processes: insular sensitivity to phonology". Brain Topogr 18 (4): 233-9.

[4] Long, M. (1985). Input and Second Language Acquisition Theory. In S. Gass\& C.Madden (eds.), Input and Second Language Acquisition[M]. Rowley, Mass.:Newbury House.

[5] J. L Liu, A study of English listening teaching based on the whole language approach, China Technology Information 4, 2006.

[6] X. Zhang, A brief study of teaching college English listening from the perspective of whole language approach, China Technology Information 19, pp. 284-285, 2010.

[7] Goodman, Yetta (2005). Reading Miscue Inventory. Katonah, NY: Robert C. Owen Publishers, Inc.

[8] Goodman, Kenneth (1982). Language and Literacy. Boston, MA: Routledge \& Kegan. 